\title{
Pengaruh Motivasi Kerja dan Budaya Organisasi terhadap Kinerja Karyawan Pada PT. Citra Harapan Anugrah
}

\author{
Johansen Dayani dan Carol Daniel Kadang \\ Program Studi Manajemen, Fakultas Ekonomi dan Bisnis, \\ Universitas Tarumanagara \\ Email: dayani.johansen@yahoo.com
}

\begin{abstract}
This study aims to analyze the effect of work motivation and organizational culture on employee performance at PT Citra Harapan Anugrah in Jakarta. This research was conducted with a probability sampling method with a simple random sampling type. Researchers distributed questionnaires to 52 employees of PT Citra Harapan Anugrah. Data analysis using Smart PLS analysis. The results of the analysis concluded that work motivation and organizational culture significantly influence the performance of employees of PT Citra Harapan Anugrah.
\end{abstract}

Keywords: work motivation, organizational culture, performance

\begin{abstract}
Abstrak: Penelitian ini bertujuan untuk menganalisis pengaruh motivasi kerja dan budaya organisasi terhadap kinerja karyawan pada PT Citra Harapan Anugrah di Jakarta. Penelitian ini dilakukan dengan metode probability sampling dengan jenis simple random sampling. Peneliti menyebarkan kuesioner kepada 52 karyawan PT Citra Harapan Anugrah. Analisis data menggunakan analisis Smart PLS. Hasil analisis menyimpulkan bahwa motivasi kerja dan budaya organisasi berpengaruh signifikan terhadap kinerja karyawan PT Citra Harapan Anugrah.
\end{abstract}

Kata kunci: motivasi kerja, budaya organisasi, kinerja

\section{LATAR BELAKANG}

Pada masa sekarang ini perusahaan di tuntut untuk meningkatkan kinerja kerja perusahaan agar dapat bersaing dengan perusahaan lain di era globalisasi sehingga perusahaan di haruskan meningkatkan kualitas karyawannya karena karyawan merupakan unsur penting di dalam perusahaan yang dapat menggerakan atau meningkatkan sebuah perusahaan. Sehingga perusahaan harus dapat memperhatikan karyawannya agar para karyawan dapat bekerja secara maksimal. Karyawan merupakan unsur terpenting di dalam sebuah perusahaan di karenakan karyawan merupakan penggerak sebuah perusahaan agar dapat berjalan sesuai dengan tujuan perusahaan. Kinerja adalah hasil kerja secara kualitas dan kuantitas yang dicapai oleh seorang karyawan dalam melaksanakan tugasnya sesuai dengan tanggung jawab yang diberikan kepadanya (Mangkunegara, 2013:18). Menurut Rivai dan Basri (2009) menjelaskan bahwa kinerja adalah hasil dari keseluruhan selama periode tertentu yang dilakukan seseorang dalam melakukan tugasnya. Seperti standar hasil kerja, target atau ketentuan yang sudah ditentukan. Maka peranan motovasi kerja dan budaya organisasi sangatlah berpengaruh terhadap kinerja karyawan karena setiap harus dapat dinyatakan keterkaitannya dan diukur dengan pencapaian tujuan organisasi di masa sekarang dan di masa yang akan datang, yang ada di dalam visi dan misi suatu organisasi. Kinerja para karyawan dapat menentukan berhasil tidaknya pelaksanaan kegiatan suatu orgnaisasi. Kinerja 
juga dapat merupakan tindakan atau pelaksanaan tugas yang telah diselesaikan oleh seseorang dalam kurun waktu tertentu dan dapat diukur.

Banyak faktor yang biasa mempengaruhi kinerja karyawan, dan saling berkaitan. Faktor yang mempengaruhi kinerja karyawan di antaranya adalah motivasi dan budaya organisasi (Munawirsyah, 2018). Menurut Gorda (2004) motivasi adalah serangkaian dorongan yang di rumuskan secara sengaja oleh perusahaan kepada karyawan agar mereka bersedia secara ikhlas melakukan prilaku tertentu yang berdampak kepada peningkatan kinerja dalam rangka pencapaian perusahaan yang telah di tetapkan sebelumnya. Sedangkan menurut Mathis \& Jackson (2006:89), menyatakan motivasi merupakan hasrat di dalam diri seseorang yang menyebabkan orang tersebut melakukan suatu tindakan untuk sesuatu hal dalam mencapai tujuan. Motivasi dapat mengarahkan dan mendorong karyawan untuk melakukan pekerjaan dengan kinerja tinggi yang sesuai harapan perusahaan. Motivasi kerja sangatlah penting di dalam suatu perusahaan karena dengan adanya motivasi kerja dapat mendorong karyawan melakukan pekerjaan yang lebih efisien dan efektif guna mencapai tujuan tertentu. Maka perusahaan harus dapat memberikan dan meningkatkan motivasi kerja kepada karyawan agar karyawan dapat bekerja secara optimal dan mencapai tujuan yang di tentukan perusahaan. Tetapi juga karyawan tidak akan dapat bekerja secara optimal jika tidak ada motivasi yang besar dari dalam diri karyawan. Maka dari itu motivasi terbagi dua faktor yaitu faktor ekstrinsik dan faktor intrinsik, dalam faktor ekstrinsik berasal dari lingkungan sekitar sedangkan dalam faktor intrinsik berasal dari dalam diri karyawan. Motivasi dapat memperlihatkan seorang karyawan untuk bekerja mencapai tujuan tertentu. Keinginan untuk memiliki jabatan yang tinggi dan mendapatkan bonus yang besar dari perusahaan menjadi motivasi karyawan bekerja secara lebih semangat di suatu perusahaan. Menurut hasil penelitian Saputri, dkk (2014) menyatakan budaya organisasi dan motivasi kerja berpengaruh signifikan dan positif terhadap kinerja karyawan. Selain itu dalam penelitian Muzaki, dkk (2017) junga menyimpulkan bahwa motivasi kerja berpengaruh signifikan terhadap kinerja karyawan.

Selain motivasi kerja, budaya organisasi juga sangat penting dalam suatu perusahaan (Munawirsyah, 2018). Menurut Abdullah dan Aristanti (2010) budaya organisasi adalah suatu keyakinan yang diyakini oleh anggota organisasi, yang berpengaruh kepada perilaku para anggota organisasi dan cara bekerjya para anggota organisasi. Dapat diartikan bahwa menjadi aturan yang tertulis atau tidak tertulis atau menjadi patokan yang diyakini oleh karyawan. Sehingga akan terbentuk sebagai tata cara kerja karyawan yang menjadi kebiasaan yang akan berdampak terhadap kinerja. Apabila suatu perusahaan memiliki budaya organisasi yang sangat kuat dalam nilai-nilai kerja, maka akan menimbulkan sinergi antara karyawan dengan baik. Sehingga para manajer atau atasan tidak kesulitan untuk menyelesaikan konflik sesama karyawan yang berbeda nilai buadaya. Dalam kehidupan sehari-hari seseorang tidak akan terlepas dari lingkungannya. Manusia yang pada dasarnya sebagai makhluk budaya mengandung pengertian bahwa kebudayaan merupakan ukuran dalam hidup dan bertingkah laku manusia terhadap lingkungannya. Pada dasarnya manusia atau seseorang yang berada dalam kehidupan organisasi berusaha untuk menentukan dan membentuk sesuatu yang dapat mengakomodasi kepentingan semua pihak agar dalam menjalankan aktivitasnya tidak berbenturan dengan berbagai sikap dan perilaku dari masing-masing individu. Kebudayaan mengikat para anggota yang dilingkupi kebudayaan itu untuk berperilaku sesuai dengan kebudayaan yang ada tanpa merasa terpaksa. Apabila budaya tersebut bersifat mengarahkan kepada anggota organisasi untuk mempunyai kinerja yang baik, maka dapat dipastikan anggota melaksanakannya dengan baik. Akhirnya pelaksanaan budaya itu akan menghasilkan output kinerja yang baik. Menurut hasil penelitian Nadhira dan Rustono (2018) menyimpulkan bahwa motivasi dan budaya organisasi berpengaruh signifikan terhadap kinerja karyawan. Dengan adanya motivasi yang tinggi dan budaya organisasi yang kuat akan 
meningkatkan kinerja karywan. Selain itu dalam penelitian Wibowo dan Putra (2016) menyatakan budaya organisasi berpengaruh terhadap kinerja karyawan. Kemudian penelitian Nuswantoro, dkk (2016) juga menyimpulkan bahwa budaya organisasi berpengaruh signifikan terhadap kinerja karyawan.

\section{KAJIAN TEORI}

Menurut Fahmi (2013:45), "motivasi kerja adalah aktivitas perilaku yang bekerja dalam usaha untuk memenuhi kebutuhan- kebutuhan yang diinginkan." Sedangkan menurut Darmadi (2018: 125): "Motivasi adalah kekuatan, baik dari dalam maupun dari luar yang mendorong seseorang untuk mencpai tujuan tertentu yang telah ditetapkan sebelumnya". Menurut Robbins and Judge (2014:222), "Motivasi adalah proses yang menjelaskan mengenai kekuatan, arah, dan ketekunan seseorang dalam upaya untuk mencapai tujuan" Menurut Sutrisno (2013:75), "motivasi adalah faktor yang mendorong seseorang untuk melakukan suatu aktivitas tertentu dan sebagai faktor pendorong perilaku seseorang".

Luthans (2011:137) mengemukakan bahwa budaya organisasi adalah pola pemikiran dasar yang diajarkan kepada personel baru sebagai cara untuk merasakan, berfikir dan bertindak secara benar dari hari-kehari. Robbins dan Judge (2014:256) berpendapat bahwa: "Budaya oranisasi mengacu ke sistem makna bersama yang dianut oleh anggota-anggota yang membedakan organisasi itu dari organisasiorganisasi lain. Sistem maksa bersama ini, bila diamati dengan lebih seksama, merupakan seperangkat karakteristik utama yang dihargai oleh organisasi itu." Suwarto dan Koeshartono (2010:102) mengemukakan bahwa: "Secara umum, perusahaan atau organisasi terdiri atas sejumlah orang dengan latar belakang, kepribadiam, emosi dan ego yang beragam. Hasil penjumlahan dan interaksi berbagai orang tersebut membentuk budaya organisasi. Secara sederhana, budaya organisasi dapat didefinisikan sebagai kesatuan orang-orang yang memiliki tujuan, keyakinan (beliefs), dan nilai-nilai yang sama."

Menurut Sedarmayanti (2011:51) memberikan pengertian sebagai berikut : "Kinerja merupakan "hasil atau keluaran dari hasil" hasil yang dimaksud adalah hasil dari sikap ataupun pekerjaan dari pegawai". Menurut Dessler (2007:84) "kinerja karyawan merupakan prestasi kerja, yakni perbandingan antara hasil kerja yang dapat dilihat secara nyata dengan standar kerja yang telah ditetapkan organisasi". Menurut Mangkunegara (2013:9) "Kinerja adalah hasil kerja secara kualitas dan kuantitas yang dicapai oleh seorang karyawan dalam melaksanakan tugasnya sesuai dengan tanggung jawab yang diberikanya”.

Pengaruh Motivasi Terhadap Kinerja Karyawan. Motivasi merupakan variabel penting, yang dimana motivasi perlu mendapat perhatian yang besar bagi organisasi dalam peningkatan kinerja karyawannya. Motivasi kerja adalah dorongan atau semangat yang timbul dalam diri seseorang atau karyawan untuk melakukan sesuatu atau bekerja, karena adanya rangsangan dari luar baik itu dari atasan dan lingkungan kerja, serta adanya dasar untuk memenuhi kebutuhan dan rasa puas, serta memenuhi tanggung jawab atas tugas-tugas yang diberikan dan dilakukan dalam organisasi (Bryan, 2014).

Dalam organisasi seorang pegawai dituntut untuk lebih giat dan aktif dalam bekerja. Untuk mencapai hal tersebut diperlukan adanya motivasi dalam melakukan pekerjaan, karena seorang pegawai yang mempunyai motivasi kerja yang tinggi biasanya mempunyai kinerja yang tinggi pula. Motivasi merupakan faktor yang dapat mempengaruhi kinerja pegawai, kurangnya motivasi yang diberikan berdampak pada menurunnya kinerja pegawai (Resa, Sientje dan Altje, 2015).

Setiap pegawai membutuhkan dorongan positif dalam melaksanakan pekerjaan. Kebutuhan individu ini akan mempengaruhi semangat kerjanya. Pemberian motivasi 
bertujuan untuk mendorong pegawai agar lebih semangat dan bergairah dalam bekerja. Semangat dan gairah kerja seorang pegawai dapat ditingkatkan dengan pemberian motivasi kerja yang tinggi. Jadi dengan memberikan motivasi dapat meningkatkan kinerja pegawai Frederic et.al (2013).

Dalam penelitian Munawirsyah (2018) menyimpulkan bahwa motivasi kerja berpengaruh terhadap kinerja karyawan. Hasil penelitian ini memperkuat hasil penelitian yang dilakukan oleh Demikian juga Muzaki, dkk (2017) dan Saputri, dkk (2014) juga menyatakan bahwa motivasi berpengaruh terhadap kinerja karyawan

Pengaruh Budaya Organisasi Terhadap Kinerja Karyawan. Budaya organisasi adalah suatu tatanan keyakinan yang diyakini oleh anggota organiasasi, yang akan berdampak pada perilaku dan cara bekerjanya anggota organisasi. Yang menjelaskan bahwa didalam budaya organisasi merupakan suatu sistem penyebaran nilai-nilai dan kepercayaan yang berkembang dan dapat mengarahkan perilaku anggota-anggotanya didalam suatu organisasi. Organisasi yang dapat memiliki nilai-nilai kepribadian organisasi bila suatu organisasi dapat mengarahkan para karyawannya dalam bertindak dan memahami keseluruhan nilai-nilai organiasasi. Dengan karyawan yang berperilaku dan menerapkan budaya organiasi dalam hal bekerja maka akan berdampak positif dan memberikan kinerja yang baik kepada organisasi.

Hal ini sependapat dengan Nadhira dan Rustono (2018) menjelaskan bahwa budaya organisasi merupakan hasil dari interaksi dan kebiasaan yang mempengaruhi kelompkkelompok anggota dan juga lingkungan organisasi. Sehingga akan membentuk pandangan yang bersifat subjektif terhadap organisasinya bedasarkan pada faktor-faktor seperti tekanan pada tim, toleransi resiko, dukungan sekitar. Maka persepsi ini akan menjadi budaya dan kepribadian-kepribadian dari suatu organisasi yang mampu mendorong dan mendukung karyawan dalam berkerja. Selain itu dalam penelitian Wibowo dan Putra (2016) serta penelitian Nuswantoro, dkk. (2016) juga menyimpulkan bahwa budaya organisasi berpengaruh signifikan terhadap kinerja karyawan.

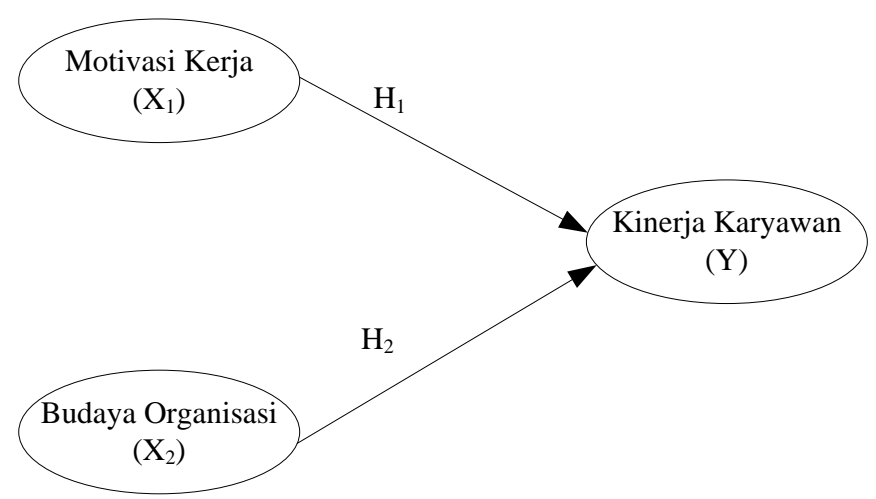

Gambar 1. Kerangka Pemikiran

Berdasarkan kerangka pemikiran diatas maka hipotesis penelitian ini adalah sebagai berikut:

H1 : Motivasi Kerja (X1) mempengaruhi Kinerja Karyawan (Y).

H2 : Budaya Organisasi (X2) mempengaruhi Kinerja Karyawan (Y).

\section{METODOLOGI}

Penelitian ini menggunakan disain penelitian deskriptif yang bertujuan membuat deskriptif secara sistematis, faktual, dan akurat mengenai fakta-fakta dan sifat-sifat dari populasi. Melalui penerapan metode deskriptif diharapkan peneliti mendapatkan informasi 
yang tepat dan akurat serta gambaran dari pengaruh motivasi kerja (X1) dan budaya organisasi (X2) terhadap kinerja karyawan (Y). Populasi dalam penelitian ini adalah seluruh karyawan PT. Citra Harapan Anugrah sebanyak 60 karyawan. Jumlah sampel sebanyak 52 responden

Data dianalisis menggunakan PLS-SEM dimana data diolah dengan program software SmartPLS 3. Pertama, pengolahan dilakukan pada outer model untuk menguji validitas (konvergen dan diskriminan) dan reliabilitas. Uji validitas konvergen dilihat dari nilai outer loadings di antara 0,5-0,7 kemudian AVE > 0,5. Selanjutnya untuk uji validitas diskriminan, beracuan pada Fornell-Larcker Criterion dan Cross Loadings (Garson, 2016). Kemudian pada analisis reliabilitas, beracuan pada nilai cronbach's alpha dan composite reliability > 0,7 (Ghozali dan Latan, 2015:75).

Kedua, pengolahan dilakukan pada inner model untuk menguji hipotesis yang telah dihasilkan. Sebelum pengujian hipotesis, pertama dilakukan pengujian hubungan antar konstruk dengan melihat nilai $\mathrm{R}$-square $\left(\mathrm{R}^{2}\right)$ dengan kriteria $(1-0,75)$ "bersifat kuat", $(0,74$ - 0,5) "bersifat moderat", dan (0,49 - 0,25) "bersifat lemah" (Ghozali dan Latan, 2015:78), nilai Q-square $\left(\mathrm{Q}^{2}\right)$ dengan kriteria $\mathrm{Q}^{2}>0$ “memiliki kemampuan prediksi” (Chin, 2010), dan nilai GoF (Goodness of Fit) dengan kriteria 0,1 "kelayakan model kecil", 0,25 "kelayakan model sedang", dan 0,36 "kelayakan model besar" (Tenenhaus, 2005). Selanjutnya pengujian hipotesis, untuk melihat pengaruh yang terjadi lihat (positif/ negatif) dari coefficient yang dihasilkan, dan menggunakan $t$-statistics $>1,645$ (hipotesis tidak ditolak) dan $p$-values $<0,05$ (hipotesis signifikan) (Haryono, 2017:40).

\section{HASIL UJI STATISTIK}

\section{Hasil Uji validitas}

Pada hasil validitas konvergen, didapatkan semua angka $>0,5$ pada nilai outer loadings untuk setiap pernyataannya, dan didapatkan semua angka $>0,5$ pada nilai Average Variance Extracted / AVE maka pernyataan yang digunakan sudah valid secara validitas konvergen. Selain itu, pada hasil validitas diskriminan, peneliti menggunakan nilai Cross Loadings dimana nilai korelasi antara pernyataan terhadap variabel nya sendiri harus lebih besar daripada pernyataan terhadap variabel lainnya berdasarkan hasil kalkulasi SmartPLS 3, didapatkan semua angka pada pernyataan terhadap variabel-nya sendiri lebih besar daripada terhadap variabel lainnya maka pernyataan sudah valid secara validitas diskriminan.

\section{Hasil Uji reliabilitas}

Pada hasil reliabilitas, maka berdasarkan hasil yang dikalkulasi oleh program SmartPLS 3, didapatkan semua angka pada nilai Cronbach's Alpha untuk setiap pernyataannya adalah $>0,7$ dan pada nilai Composite Reliability didapatkan semua angka untuk setiap pernyataannya adalah $>0,7$. Maka pernyataan yang digunakan dalam penelitian ini sudah reliabel berdasarkan kedua nilai reliabilitas, yakni Cronbach's Alpha dan Composite Reliability.

\section{Hasil Uji R-Square ( $\mathbf{R}^{\mathbf{2}}$ ) dan GoF (Goodness of Fit)}

Dapat diketahui nilai $R$ Square adalah sebesar 0,582 , artinya sebesar $58.2 \%$ variasi kinerja karyawan dapat dijelaskan oleh variasi motivasi kerja dan budaya organisasi. Sisanya sebesar $41,8 \%$ dijelaskan oleh variabel lain.

Hasil uji GoF, didapatkan nilai GoF sebesar 0,625 yang berarti bahwa keseluruhan dalam kinerja model prediksi yang ditinjau pada tingkat kesesuaian antara inner model dengan outer model adalah besar karena di atas 0,36 . 


\section{Hasil Uji Hipotesis}

Tabel 1. Hasil Uji Hipotesis (Bootstrapping)

\begin{tabular}{|l|c|c|c|c|c|}
\hline & $\begin{array}{c}\text { Original } \\
\text { Sample } \\
(\mathrm{O})\end{array}$ & $\begin{array}{c}\text { Sample } \\
\text { Mean } \\
(\mathrm{M})\end{array}$ & $\begin{array}{c}\text { Standar } \\
\text { Deviation } \\
\text { (STDEV) }\end{array}$ & $\begin{array}{c}\text { T Statistics } \\
(\mathrm{JO} / \text { STDEV) }\end{array}$ & $\begin{array}{c}\mathrm{P} \\
\text { Value }\end{array}$ \\
\hline $\begin{array}{l}\text { Motivasi Kerja } \rightarrow \\
\text { Kinerja Karyawan }\end{array}$ & 0.433 & 0.425 & 0.171 & 2.533 & 0.012 \\
\hline $\begin{array}{l}\text { Motivasi Kerja } \rightarrow \\
\text { Kinerja Karyawan }\end{array}$ & 0.365 & 0.380 & 0.120 & 3.042 & 0.002 \\
\hline
\end{tabular}

Sumber: Hasil Olah Data pada SmartPLS3

\section{DISKUSI}

Hipotesis yang pertama menunjukkan bahwa variabel motivasi kerja terbukti berpengaruh secara signifikan terhadap kinerja karyawan karena hasil dari nilai t-statistik inovasi sebesar 2,533 yang berarti lebih besar dari 1,96 dan p-values sebesar 0,012 yang berarti lebih kecil dari 0,05. Sehingga dapat disimpulkan bahwa motivasi kerja memiliki pengaruh yang signifikan terhadap kinerja karyawan. Hasil ini sesuai dengan penelitian Munawirsyah (2018), Muzaki, dkk (2017) dan Saputri, dkk (2014) yang menyatakan bahwa motivasi berpengaruh terhadap kinerja karyawan. Motivasi merupakan variabel penting, yang dimana motivasi perlu mendapat perhatian yang besar bagi organisasi dalam peningkatan kinerja karyawannya. Motivasi kerja adalah dorongan atau semangat yang timbul dalam diri seseorang atau karyawan untuk melakukan sesuatu atau bekerja, karena adanya rangsangan dari luar baik itu dari atasan dan lingkungan kerja, serta adanya dasar untuk memenuhi kebutuhan dan rasa puas, serta memenuhi tanggung jawab atas tugas-tugas yang diberikan dan dilakukan dalam organisasi. Setiap pegawai membutuhkan dorongan positif dalam melaksanakan pekerjaan. Kebutuhan individu ini akan mempengaruhi semangat kerjanya. Pemberian motivasi bertujuan untuk mendorong pegawai agar lebih semangat dan bergairah dalam bekerja. Semangat dan gairah kerja seorang pegawai dapat ditingkatkan dengan pemberian motivasi kerja yang tinggi. Jadi dengan memberikan motivasi dapat meningkatkan kinerja pegawai.

Kemudian untuk hipotesis kedua menunjukkan bahwa variabel pengambilan budaya organisasi memiliki nilai t-statistik sebesar 3,042 yang berarti lebih besar dari 1,96 dan pvalues sebesar 0,002 yang berarti lebih kecil dari 0,05. Sehingga dapat disimpulkan bahwa budaya organisasi memiliki pengaruh yang signifikan terhadap kinerja karyawan. Hasil ini sesuai dengan penelitian Nadhira dan Rustono (2018), Wibowo dan Putra (2016) serta penelitian Nuswantoro (2016) yang menyimpulkan bahwa budaya organisasi berpengaruh signifikan terhadap kinerja karyawan. Budaya organisasi adalah suatu tatanan keyakinan yang diyakini oleh anggota organiasasi, yang akan berdampak pada perilaku dan cara bekerjanya anggota organisasi. Yang menjelaskan bahwa didalam budaya organisasi merupakan suatu sistem penyebaran nilai-nilai dan kepercayaan yang berkembang dan dapat mengarahkan perilaku anggota-anggotanya didalam suatu organisasi. Organisasi yang dapat memiliki nilai-nilai kepribadian organisasi bila suatu organisasi dapat mengarahkan para karyawannya dalam bertindak dan memahami keseluruhan nilai-nilai organiasasi. Dengan karyawan yang berperilaku dan menerapkan budaya organiasi dalam hal bekerja maka akan berdampak positif dan memberikan kinerja yang baik kepada organisasi. 


\section{PENUTUP}

Berdasarkan penelitian dan pembahasan, maka dapat diambil beberapa kesimpulan sebagai berikut:

1. Motivasi kerja berpengaruh signifikan terhadap kinerja karyawan pada PT. Citra Harapan Anugrah. Semakin baik Motivasi yang diberikan oleh perusahaan maka akan semakin meningkatkan kinerja karyawan.

2. Budaya Organisasi berpengaruh signifikan terhadap kinerja karyawan pada PT. Citra Harapan Anugrah. Budaya organisasi yang baik akan semakin baik meningkatkan kinerja karyawan.

Berdasarkan hasil penelitian yang ada, maka beberapa saran yang dapat diberikan adalah:

1. Untuk lebih meningkatkan kinerja karyawan, maka dari pihak pimpinan perlu memberikan perhatian lebih terhadap upaya-upaya untuk menciptakan iklim organisasi yang kondusif, bersikap adil dengan sesama pegawai, saling mengingatkan jika melakukan kesalahan dan bersikap terbuka. Selain itu pimpinan harus memberikan motivasi yang lebih kepada karyawannya agar mereka bekerja lebih giat untuk meningkatkan kinerja mereka.

2. Bagi para pengusaha diharapkan perlu membuat kebijakan dan program yang dapat membangun budaya organisasi yang mengutamakan kepentngan konsumen dan meningkatkan komitmen karyawan, sehingga diharapkan apabila komitmen yang tinggi maka organisasi akan lebih mudah membangun budaya organisasi yang berfokus pada keberhasilan perusahaan.

3. Bagi peneliti selanjutnya yang tertarik untuk meneliti mengenai kinerja karyawan, ada baiknya menghubungkan dengan variabel lain yang mungkin berpengaruh yang belum di teliti dalam penelitian ini seperti kompensasi, lingkungan kerja, dan sebagainya.

\section{DAFTAR PUSTAKA}

Bryan Johannes Tampi (2014) Pengaruh gaya kepemimpinan dan motivasi terrhadap kinerja karyawan pada PT. Bank Negara Indonesia,Tbk (regional sales manado). Journal Acta Diurna . Volume III. No.4. hal. 1.20

Darmadi (2018) Manajemen Sumber Daya Manusia. Yogyakarta: Budi Utama

Dessler, Gary. (2007). Manajemen sumber daya manusia, Jilid II, Jakarta: Indeks

Fahmi, Irham. (2014). Perilaku Organisasi: Teori, Aplikasi, dan Kasus. Cetakan Kedua. Bandung: Alfabeta.

Frederick Binfor, Sampson Kwadwo Boateng, Edith Anokor Abbey Samuel Adu Osei, Felix K. M. Swanzy dan Theophilus Francis Gyepi-Garbrah (2013) The effect of leadership styles and motivation on employee performance in public institutions: evidence from Ghana. International Journal of Current Research. Vol. 5, Issue, 09, pp.2667-2670

Gorda. (2004). Manajemen Sumber Daya Manusia. Denpasar: Widya Kriya Gematama

Luthans, Fred. (2011). Organizational Behavior : An Evidence-Based Approach. New York: McGraw-Hill

Mangkunegara, Anwar Prabu. (2013). Manajemen Sumber Daya Manusia Perusahaan. Bandung: Remaja Rosdakarya

Mathis, R dan Jackson, W.(2006). Human Resources Development (Track MBA series/terjemahan). Jakarta; Prestasi Pustaka 
Munawirsyah, Isnan (2018) Pengaruh Motivasi Kerja Dan Budaya Organisasi Terhadap Kinerja Karyawan Pada PT. Perkebunan Nusantara III Medan. Jurnal Bisnis Administrasi. Vol 07, No 02: 33-39

Muzakki, Muhammad Alkirom Wildan dan Helmi Buyung Aulia Safrizal (2017) Pengaruh Budaya Organisasi, Motivasi Kerja Dan Organizational Citizenship Behavior Terhadap Kinerja Pegawai Pemerintah Kabupaten Pamekasan. Jurnal Kompetensi, Vol 11, No 1: 109-128

Nadhira, Siti Rahma dan Anthon Rustono (2018) Pengaruh Budaya Organisasi Dan Motivasi Terhadap Kinerja Karyawan (Studi Kasus Pada Pt Telekomunikasi Indonesia Witel Jakarta Selatan Unit HR\&CDC Dan Network Area). e-Proceeding of Management. Vol.5, No.1: 260-267.

Nuswantoro, Agrona Brajahadi, Alwi Suddin dan Ernawati (2016) Pengaruh Motivasi Dan Budaya Organisasi Terhadap Kinerja Karyawan Dengan Kompensasi Sebagai Variabel Moderasi. Jurnal Manajemen Sumber Daya Manusia. Vol. 10 No.1 : 67 - 75

Resa R. Jacob, Sientje C. Nangoy dan Altje L. Tumbel (2015) Gaya kepemimpinan dan motivasi kerja pengaruhnya terhadap kinerja pegawai bagian administrasi umum sekretariat daerah kab. kepulauan Siau Tagulandang Biaro . Jurnal EMBA. Vol.3 No.3, Hal.373-381

Robbins, Stephen P dan Judge, Timothy A. (2014). Perilaku Organisasi. Edisi 12. Jakarta: Selemba Empat.

Saputri, Laras Tri, Achmad Fudholi dan Sumarni (2014) Pengaruh Motivasi Kerja Dan Budaya Organisasi Terhadap Kinerja Karyawan. Jurnal Manajemen dan Pelayanan Farmasi. Vol. 4 No. 1: 63-68

Sedarmayanti. (2011). Manajemen Sumber Daya Manusia, Reformasi Birokrasi dan Manajemen Pegawai Negeri Sipil (cetakan kelima). Bandung: Refika Aditama.

Sutrisno, Edy (2013). Sumber Daya Manusia. Jakarta: Kencana

Suwarto, F.X. dan Koeshartono, D., (2010), Budaya Organisasi: Kajian Konsep dan Implementasi. Yogyakarta: Universitas Atma Jaya Yogyakarta.

Wibowo, Mada Adi dan Yanuar Surya Putra (2016) Pengaruh Motivasi Dan Budaya Organisasi Terhadap Kepuasan Kerja Serta Implikasinya Terhadap Kinerja Karyawan Pada Rumah Sakit Umum (RSU) Salatiga. Among Makarti. Vol.9 No.17: $1-20$. 